Tri Panjiasih Susmiarsih, Kenconoviyati, Kuslestari. (2018). Pengaruh Pembelajaran Ekstrak Daun Teh Hijau Terhadap Konsentrasi dan Kecepatan Spermatozoa Tikus (Rattus Norvegicus) Setelah Paparan Asap Rokok. Jurnal Bioeksperimen. Vol. 4 (2) Pp. 46-51. Doi: 10.23917/bioeksperimen.v4i1.2795

\title{
Pengaruh Pemberian Ekstrak Daun Teh Hijau Terhadap Konsentrasi dan Kecepatan Spermatozoa Tikus (Rattus norvegicus) Setelah Paparan Asap Rokok
}

\author{
Tri Panjiasih Susmiarsih ${ }^{1}$, Kenconoviyati ${ }^{2}$, Kuslestari $^{2}$ \\ ${ }^{1}$ Bagian Biologi Fakultas Kedokteran Universitas YARSI, \\ ${ }^{2}$ Bagian Hisiologi Fakultas Kedokteran Universitas YARSI \\ Jl. Letjend Suprapto Cempaka Putih Jakarta Pusat 10510 \\ e-mail: susmiarsih@gmail.com
}

\begin{abstract}
Abstrak
Merokok dapat menyebabkan berbagai macam gangguan kesehatan, asap rokok mengandung bahan kimia berbahaya dan radikal bebas yang berpotensi menimbulkan infertilitas. Teh (Camelia sinensis) merupakan tumbuhan yang banyak mengandung polifenol flavonoid katekin (sekitar 30\%-40\%), senyawa ini berpotensi sebagai antioksidan kuat untuk menetralisir efek toksik radikal bebas. Tujuan penelitian ini adalah mengetahui pengaruh pemberian ekstrak daun teh hijau terhadap konsentrasi dan kecepatan spermatozoa tikus (Rattus norvegicus) setelah paparan asap rokok.

Subjek penelitian menggunakan 24 ekor tikus putih. Perlakuan terbagi atas: kelompok kontrol (K1 dan K2), kelompok paparan asap rokok dan pemberian ekstrak teh hijau (P1 dan P5), kelompok paparan asap rokok (P2 dan P5) dan kelompok pemberian ekstrak teh hijau (P3 dan P6). Periode perlakuan selama 30 hari (K1,P1,P2,P3) dan 45 hari (K2,P4,P5,P6). Dosis paparan asap rokok sebanyak 1 batang per hari dan ekstrak daun teh hijau sebanyak $200 \mathrm{mg} / \mathrm{kg}$ bb. Semen diperoleh dari epididimis bagian kaudal tikus. Analisis data konsentrasi dan kecepatan spermatozoa menggunakan uji ANOVA dan uji perbandingan LSD.

Hasil penelitian menunjukkan pemberian ekstrak daun teh hijau mampu mempertahankan kecepatan gerak spermatozoa tikus setelah paparan asap rokok, namun pemberian ekstrak daun teh hijau tidak dapat memperbaiki konsentrasi spermatozoa setelah paparan asap rokok. Ekstrak daun teh hijau diindikasikan dapat memperbaiki kualitas spermatozoa.
\end{abstract}

Kata kunci: teh hijau, spermatozoa, rokok

\section{Pendahuluan}

Di Indonesia penggunaan tembakau merupakan salah satu penyebab utama terjadinya sakit diantara penduduk miskin dan lebih dari $97 \%$ orang tidak merokok terpapar asap rokok (Barber et al. 2008). Merokok dapat menyebabkan berbagai macam gangguan kesehatan, asap rokok mengandung bahan kimia berbahaya dan radikal bebas yang berpotensi menimbulkan infertilitas. Asap rokok mengandung senyawa-senyawa sumber radikal bebas terbesar yaitu: tar, nikotin, karbonmonoksida dan PAH (Poly-nuclear
Aromatic Hydrogen), senyawa-senyawa tersebut dapat menyebabkan infertilitas dengan ditandai penurunan parameter dan fungsi semen dan kematian spermatozoa (Roychoudhury et al. 2017). Nikotin menyebabkan penurunan motilitas dan jumlah sperma (Oyeyipo et al. 2011). Radikal bebas menyebabkan kerusakan integritas DNA spermatozoa hingga kematian sel. ROS yang timbul karena asap rokok berpengaruh terhadap fungsi sel Sertoli dan sel Leydig di testis dan menyebabkan gangguan kualitas spermatozoa

Radikal bebas asap rokok dapat dinetralisir dengan pemberian antioksidan eksogen 
seperti superoksida dismutase, katalase, glutation peroksidase, vitamin $\mathrm{A}, \mathrm{D}, \mathrm{E}$, dan $\mathrm{C}$, namun penggunaan antioksidan tersebut masih terkendala oleh keterbatasan bahan dan harga yang tidak terjangkau oleh masyarakat. Untuk itu dicari antioksidan yang berasal dari tumbuhan yang banyak dibudidayakan di Indonesia, diantaranya daun teh hijau, yang sering dikonsumsi oleh masyarakat. Daun teh hijau mengandung flavonoid katekin, terutama epigallocatechin-3-gallate,yang bermanfaat bagi kesehatan (Chako et al. 2010; Suzuki et al. 2016). Jenis-jenis katekin yang ditemukan dalam teh hijau diantaranya epicatechin (EC), epicatechin-2-gallate (ECG), epigallocatechin (EGC) dan epigallocatechin-3-gallate (EGCG). EGCG merupakan katekin terbanyak (sekitar 50-80\% dari katecin total) (Namita et al. 2012). Katekin berfungsi sebagai antioksidan yang dapat menurunkan radikal bebas (Chako et al. 2010; Suzuki et al. 2016).

Dari uraian di atas, daun teh hijau mempunyai prospek sebagai bahan antioksidan alami dalam memperbaiki kualitas spermatozoa akibat paparan radikal bebas sehingga perlu diteliti pengaruh pemberian ekstrak daun teh hijau terhadap konsentrasi dan kecepatan spermatozoa tikus (Rattus norvegicus) setelah paparan asap rokok.

\section{Metode}

Penelitian menggunakan 24 ekor tikus putih, yang dibagi atas beberapa kelompok perlakuan yaitu kelompok kontrol (K1 dan K2), kelompok paparan asap rokok dan pemberian ekstrak teh hijau (P1 dan P5), kelompok paparan asap rokok (P2 dan P5) dan kelompok pemberian ekstrak teh hijau (P3 dan P6). Periode perlakuan selama 30 hari (K1,P1,P2,P3) dan 45 hari $(\mathrm{K} 2, \mathrm{P} 4, \mathrm{P} 5, \mathrm{P} 6)$. Dosis paparan asap rokok sebanyak 1 batang per hari dan ekstrak daun teh hijau sebanyak $200 \mathrm{mg} / \mathrm{kg}$ bb. Semen diperoleh dari epididimis bagian kaudal dari tikus dan ekstraksi daun teh hijau dengan cara maserasi

Konsentrasi spermatozoa diukur dengan menempatkan $10 \quad$ 『l larutan campuran spermatozoa (10 $\bigotimes$ l spermatozoa dilarutkan ke dalam 190 凶l Na Cl 3\%) ke dalam bilik hitung Improved Neubauer, dihitung spermatozoa di bawah mikroskop dengan perbesaran 400x pada lima kotak kecil (satu kotak kecil di tengah dan empat di setiap sudut kotak besar). Jumlah spermatozoa terhitung dikalikan dengan 50, prosedur diulangi sampai dua kali dan dibuat rerata konsentrasi spermatozoa dalam juta/ sampel.

Kecepatan spermatozoa diukur dengan menghitung waktu yang diperlukan oleh 1 sperma untuk menempuh jarak lintas 8 kotak (200 $\nabla \mathrm{m})$ Hemacytometer Nebauer. Setiap pengamatan kecepatan sperma dilakukan sebanyak tiga kali pengulangan dari sperma yang bergerak lurus. Analisis data konsentrasi dan kecepatan spermatozoa menggunakan uji ANOVA dan uji perbandingan LSD.

\section{Hasil Penelitian dan Pembahasan}

Hasil pengamatan terhadap konsentrasi spermatozoa tikus putih yang diberi beberapa perlakuan asap rokok dan ekstrak daun teh hijau dapat dilihat pada tabel 1 . 
Tabel 1. Konsentrasi Spermatozoa Tikus Putih Galur Wistar (Rattus norvegicus) setelah Paparan Asap Rokok dan Ekstrak Daun Teh Hijau

\begin{tabular}{|c|c|c|c|c|}
\hline \multirow{2}{*}{$\begin{array}{l}\text { Waktu Per- } \\
\text { lakuan } \\
\text { (hari) }\end{array}$} & \multicolumn{4}{|c|}{ Konsentrasi SpermatozoaTikus Putih (juta/mL) } \\
\hline & $\begin{array}{l}\text { Kontrol } \\
\text { (K1) }\end{array}$ & $\begin{array}{c}\text { Paparan } \\
\text { Asap rokok } \\
\text { dan Teh Hijau (P1) }\end{array}$ & $\begin{array}{c}\text { Paparan } \\
\text { Asap Rokok (P2) }\end{array}$ & $\begin{array}{c}\text { Paparan Ekstrak } \\
\text { Teh Hijau (P3) }\end{array}$ \\
\hline \multirow{3}{*}{30} & 30.3 & 26.0 & 25.0 & 28.1 \\
\hline & 41.0 & 31.2 & 27.2 & 32.5 \\
\hline & 27,1 & 30.3 & 35.5 & 33.1 \\
\hline \multirow[t]{2}{*}{ Rata-rata } & 32.80 & 29.17 & 29.33 & 31.23 \\
\hline & $\begin{array}{l}\text { Kontrol } \\
\text { (K2) }\end{array}$ & $\begin{array}{c}\text { Paparan } \\
\text { Asap rokok } \\
\text { dan Teh Hijau (P4) }\end{array}$ & $\begin{array}{c}\text { Paparan } \\
\text { Asap Rokok (P5) }\end{array}$ & $\begin{array}{c}\text { Paparan Ekstrak } \\
\text { Teh Hijau (P6) }\end{array}$ \\
\hline \multirow{3}{*}{45} & 36.0 & 25.2 & 19.3 & 36.3 \\
\hline & 33.0 & 23.1 & 18.5 & 31.5 \\
\hline & 32.3 & 26.3 & 20.5 & 33.3 \\
\hline Rata-rata & 33.77 & 24.87 & 19.43 & 33.70 \\
\hline
\end{tabular}

Dari hasil uji statistik ANOVA dan uji perbandingan beragam LSD (Tabel 2) menunjukkan ada penurunan secara bermakna $(\mathrm{p}=0.03 ; \mathrm{p}<0.05)$ konsentrasi spermatozoa tikus putih yang dipapar asap rokok (P5) dibanding kontrol (K2). Hasil pengamatan ini membuktikan ada pengaruh asap rokok terhadap penurunan konsentrasi spermatozoa tikus. Dari pengamatan juga membuktikan bahwa pemberian ekstrak daun teh hijau pada tikus putih yang dipapar asap rokok selama 45 hari belum dapat meningkatkan konsentrasi spermatozoa tikus putih (tabel 2).

Tabel 2. Analisis Uji LSD Kontrol terhadap Konsentrasi Spermatozoa Tikus Putih Galur Wistar (Rattus norvegicus) Setelah Paparan Asap Rokok dan Ekstrak Daun Teh Hijau

\begin{tabular}{ccccccccc}
\hline Perlakuan & K1 & P1 & P2 & P3 & K2 & P4 & P5 & P6 \\
\hline K1 & - & 0.252 & 0.261 & 0.615 & 0.756 & $0.020^{*}$ & $0.000^{*}$ & 0.772 \\
K2 & 0.756 & 0.152 & 0.158 & 0.420 & - & $0.010^{*}$ & $0.000^{*}$ & 0.983 \\
\hline \multicolumn{10}{c}{ * Signifikan dengan nilai $\mathrm{p}<0.05$} & &
\end{tabular}

Hasil pengamatan terhadap kecepatan gerak spermatozoa tikus putih yang diberi beberapa perlakuan asap rokok dan ekstrak daun teh hijau dapat dilihat pada tabel 3. Dari hasil uji statistik ANOVA dan uji perbandingan beragam LSD (Tabel 4) menunjukkan ada penurunan secara bermakna $(\mathrm{p}<0.05)$ konsentrasi spermatozoa tikus putih yang dipapar asap rokok (P2 dan P5) dibanding kontrol (K1 dan K2). Hasil pengamatan ini membuktikan ada pengaruh asap rokok terhadap penurunan konsentrasi spermatozoa tikus. Dari pengamatan juga membuktikan bahwa pemberian ekstrak daun teh hijau pada tikus putih yang dipapar asap rokok dapat meningkatkan kecepatan gerak spermatozoa tikus putih yang dipapar asap rokok dengan pemberian ekstrak daun teh hijau. 
Tabel 3. Kecepatan Gerak Maju Spermatozoa Tikus Putih Galur Wistar (Rattus norvegicus)

\begin{tabular}{|c|c|c|c|c|}
\hline \multirow{2}{*}{$\begin{array}{l}\text { Waktu } \\
\text { Perlakuan } \\
\text { (hari) }\end{array}$} & \multicolumn{4}{|c|}{ Kecepatan Gerak SpermatozoaTikus Putih ( $\mu \mathrm{m} /$ detik) } \\
\hline & $\begin{array}{l}\text { Kontrol } \\
\text { (K1) }\end{array}$ & $\begin{array}{c}\text { Paparan } \\
\text { Asap rokok } \\
\text { dan Teh Hijau (P1) }\end{array}$ & $\begin{array}{c}\text { Paparan } \\
\text { Asap Rokok (P2) }\end{array}$ & $\begin{array}{c}\text { Paparan Ekstrak } \\
\text { Teh Hijau (P3) }\end{array}$ \\
\hline \multirow{3}{*}{30} & 98.63 & 80.63 & 77.40 & 86.21 \\
\hline & 81.60 & 85.32 & 85.32 & 78.13 \\
\hline & 84.26 & 79.87 & 72.23 & 87.11 \\
\hline \multirow[t]{2}{*}{ Rata-rata } & 88.16 & 81.94 & 78.32 & 83.82 \\
\hline & $\begin{array}{l}\text { Kontrol } \\
\text { (K2) }\end{array}$ & $\begin{array}{c}\text { Paparan } \\
\text { Asap rokok } \\
\text { dan Teh Hijau (P4) }\end{array}$ & $\begin{array}{c}\text { Paparan } \\
\text { Asap Rokok (P5) }\end{array}$ & $\begin{array}{c}\text { Paparan Ekstrak } \\
\text { Teh Hijau (P6) }\end{array}$ \\
\hline \multirow{3}{*}{45} & 82.88 & 79.87 & 74.90 & 90.25 \\
\hline & 97.28 & 88.34 & 70.29 & 81.43 \\
\hline & 93.63 & 93.64 & 65.16 & 80.65 \\
\hline Rata-rata & 91.26 & 87.28 & 70.12 & 84.11 \\
\hline
\end{tabular}

Tabel 4.. Analisis Uji LSD Kontrol terhadap Kecepatan Gerak Tikus Putih Galur Wistar (Rattus norvegicus) Setelah Paparan Asap Rokok dan Ekstrak Daun Teh Hijau

\begin{tabular}{ccccccccc}
\hline Perlakuan & K1 & P1 & P2 & P3 & K2 & P4 & P5 & P6 \\
\hline K1 & - & 0.244 & 0.073 & 0.410 & 0.555 & 0.866 & $0.003^{*}$ & 0.442 \\
K2 & 0.555 & 0.088 & 0.023 & 0.167 & - & 0.450 & $0.001^{*}$ & 0.183 \\
\hline \multicolumn{1}{r}{ * Signifikan } & dengan nilai $\mathrm{p}<0.05$ & &
\end{tabular}

Rokok merupakan sumber radikal bebas eksogen yang dapat menyebabkan gangguan pada sistem reproduksi. PAH dalam asap rokok mempengaruhi kerja sistem saraf pusat dengan cara menghambat kerja $\mathrm{GnRH}$ sehingga rangsangan terhadap testis berkurang dan menyebabkan testis atrofi. Penghambatan GnRH menyebabkan penurunan testosteron yang diproduksi sel Leydig. Penurunan testosteron ini berdampak pada penurunan hormon FSH dan LH akibatnya proses spermatogenesis berlangsung tidak normal (Sukmaningsih, 2009). Spermatogenesis yang tidak normal ini yang dianggap sebagai penyebab konsentrasi spermatozoa tikus menurun setelah paparan asap rokok.

Paparan terhadap asap rokok memiliki relasi yang kuat dengan kerusakan DNA yang dipicu oleh radikal oksidatif (oxidative stress) dan karsinogenesis (Patel, et al., 2008). Merokok diketahui dapat meningkatkan level radikal bebas yang memicu perusakan DNA dan berbagai basa teroksidasi. merokok juga dapat menyebabkan oksidasi glutation (GSH, antioksidan yang melindungi DNA dari kerusakan akibat ROS), menurunkan level antioksidan dalam darah, dan meningkatkan pelepasan radikal superoksida (Ziech, et al., 2011). Radikal bebas dalam jumlah berlebihan, sementara jumlah antioksidan seluler lebih sedikit, maka kondisi ini dapat menyebabkan kerusakan sel. Kerusakan sel inilah yang diduga menjadi penyebab menurun konsentrasi spermatozoa dalam semen dan penurunan kecepatan gerak sperma.

Dari hasil penelitian, penurunan kecepatan gerak spermatozoa terbukti dapat diperbaiki dengan pemberian ekstrak daun teh hijau. 
Antioksidan dari teh hijau dapat mencegah kerusakan oksidatif akibat radikal bebas pada beberapa parameter sperma seperti motilitas, abnormalitas dan konsentrasi (Sheteifa dan Morsy, 2014). Penelitian yang dilakukan oleh Abshenas et al. (2012) juga membuktikan adanya efek terapi dari ekstrak teh hijau terhadap kerusakan kualitas semen akibat hipertermia.Selain itu, pemberian ekstrak teh hijau selama 28 hari secara signifikan meningkatkan motilitas, konsentrasi dan integritas membran sperma akibat adanya senyawa polifenol dari teh hijau yang memiliki sifat antioksidan kuat. Antioksidan dari teh dapat menurunkan risiko kerusakan stress oksidatif dan peningkatan kapasitas antioksidan dalam sel untuk menangkap radikal bebas yang dapat menghambat terjadinya kerusakan pada membran sel (Awoniyi, 2010; Chaturvedula dan Prakash, 2011).

\section{Kesimpulan}

Pemberian ekstrak daun teh hijau dapat meningkatkan kecepatan gerak spermatozoa tikus putih setelah paparan asap rokok namun belum dapat memperbaiki konsentrasi spermatozoa semen tikus putih. Ekstrak daun teh hijau diindikasikan dapat memperbaiki kualitas spermatozoa.

\section{Daftar Pustaka}

Abshenas J, Babaei H, Zare MH, Allahbakhshi A, Sharififar F. 2011. The effects of grees tea (Camillia sinensis) extract on mouse semen quality after scrotal heat stress. Veternity Research Forum. 242-247

Awoniyi DO. 2010. The role of rooibos (aspalathus linearis), green tea (camellia sinensis) and commercially available rooibos and green tea antioxidant supplements on rat testicular and epididymal function. Thesis. Faculty of Health and Wellness Sciences. Cape Peninsula University of Technology.

Chako SM, Thambi PT, Kuttan R, Nishigaki I. 2010. Beneficial effects of green tea: A literature review. Chinese Medicine, 5:13.

Chaturvedula VSP, Prakash I. 2011. The aroma, taste, color and bioactive constituents of tea. Journal of Medicinal Plants Research. 5(11): 2110-2124.

Gaur SD, Talekar MS, Pathak VP. 2010. Alcohol intake and cigarettes smoking: impact of two major lifestylefactors on male infertility. Indian Journal Of Pathology And Microbiology. 53(1).

Kaur CD, Saraf S. 2011. Photochemoprotective activity of alcoholic extract of Camellia sinensis. Int J of Pharmacol. 7(3):400-404.

Mehrannia T. 2007. The effect of cigarrete smoking on semen quality of infertile men. Pak J Med Sci. 23(5):717-179.

Namita P, Mukesh R, Vijay KJ. 2012. Camellia Sinensis (Green Tea): A Review. Global Journal of Pharmacology 6 (2): 52-59.

Oyeyipo IP, Raji Y, Emikpe BO, Bolarinwa AF. 2011. Effects of nicotine on sperm characteristics and fertility profile in adult male rats: a possible role of cessation. J Reprod Infertle. 12(3):201207.

Patel BP, Rawal UW. 2008. Tobacco, antioxidant enzymes, oxidative stress, and genstic susceptibility in oral cancer. Am.J. Clin.Oncol, 31: 454-459.

Rahmani AH, Al shabrmi, Allemailem KS, Aly S, Khan. 2015 Implications of Green Tea and Its Constituents in the Prevention of Cancer via the Modulation of Cell. Signalling Pathway. Hindawi Publishing Corporation BioMed Research International. http://dx.doi. org/10.1155/2015/925640.

50-Pengaruh Pemberian Ekstrak... 
Revel AN, Raanani E, Younglai J, Xu R, Han. 2001. Resveratrol, a Natural Aryl Hydrocarbon Receptor Antagonist, Protect Sperm fromDNA Damage and Apoptosis Caused by Benzo(a) Pyrene. Reproductive Toxicology $15: 479$ - 486.

Roychoudhury S, Agarwal A, Virk G, Lam Cho C. 2017. Potential role of green tea catechins in the management of oxidative stress-associated infertility. Reproductive BioMedicine, doi: 10.1016/j.rbmo.2017.02.006

Sheteifa MAM, Morsy WA. 2014. Effect of green tea as dietary supplements (Camellia sinensis) on semen quality and testosterone. profile in rabbits J. Animal and Poultry Prod., Mansoura Univ.; 5 (1): $1-13$

Sukmaningsih A 2009. Penurunan Jumlah Spermatosit Pakiten Dan Spermatid Tubulus Seminiferus Testis Pada Mencit (Mus musculus) Yang Dipaparkan Asap Rokok. Jurnal Biologi XIII. (2) :31-35.

Suzuki T, Pervin M, Goto S, Isemura M, Nakamura, Y. 2016. Beneficial Effects of Tea and the Green Tea Catechin Epigallocatechin-3-gallate on Obesity. Molecules, 21, 1305:1-13.

Yang CS, Chung JY, Yang G, Chhabra SK, Lee MJ. 2000. Tea and Tea Polyphenols in Cancer Prevention. Symposium: Diet, Natural Products and Cancer Prevention: Progress and Promise Supplement. American Society for Nutritional Sciences:478S

Ziech D, Franco R, Pappa A, Panayjiotidis, MI. 2011. Reactive Oxygen Species (ROS) - Induced Genetic and Epigenetic. Alterations in Human Carcinogenesis. Mutation Research., 711: 167-173. 